\title{
Evolution of the retiolitid Neogothograptus (Graptolithina) and its new species from the upper Wenlock of Poland, Baltica
}

\author{
Anna Kozłowska, Alfred Lenz, and Michael Melchin \\ Acta Palaeontologica Polonica 54 (3), 2009: 423-434 doi: http://dx.doi.org/10.4202/app.2008.0022
}

Neogothograptus reticulatus sp. nov. from the upper Homerian Colonograptus praedeubeli Biozone, and N. thor-

steinssoni and N. alatiformis from the Lobograptus progenitor Biozone, are described for the first time from three localities: borehole, Baltic erratic boulder of East European Platform and Holy Cross Mountains of Poland. N. reticulatus, presently the oldest known species of Neogothograptus , is also tentatively identified from upper Homerian strata of south-eastern Australia. The two other species are previously known only from Arctic Canada, and possibly China. The morphology of the Neogothograptus reticulatus rhabdosome, its appendix, thecal profile, densely reticulated rhabdosome and genicular hoods suggest a close relationship to $N$. eximinassa from Colonograptus ludensis Biozone. $N$. reticulatus and $N$. eximinassa are most similar to Gothograptus nassa, the earliest-known retiolitid to appear immediately following the Cyrtograptus lundgreni extinction event. The biostratigraphic position of $N$. reticulatus suggests it might be considered as a potential ancestor to all younger (Ludlow) species of Neogothograptus . Cladistic analysis, however, provides no direct support for such an interpretation and, instead, suggests that Baculograptus batesi may be the ancestor. The occurrences of Neogothograptus, as well as G. nassa, from a number of Silurian terranes mostly from low paleolatitude regions, but also from high paleolatitudes, demonstrate their tolerance to a broad range of paleoenvironments.

Key words: Retiolitidae, Gothograptus, Neogothograptus, evolution, biostratigraphy, ocean currents, paleolatitude, late Wenlock, Ludlow, Silurian.

Anna Kozłowska [akd@twarda.pan.pl], Instytut Paleobiologii PAN, ul. Twarda 51/55, PL-00-818 Warszawa, Poland. Alfred Lenz [aclenz@uwo.ca], Department of Earth Sciences, University of Western Ontario, London, Ontario N6A 5B7, Canada. Michael Melchin [melchin@stfx.ca], Department of Earth Sciences, St. Francis Xavier University, Antigonish, Nova Scotia, B2G 2W5, Canada. 
This is an open-access article distributed under the terms of the Creative Commons

Attribution License (for details please see creativecommons.org), which permits unrestricted use, distribution, and reproduction in any medium, provided the original author and source are credited.

Forif Full text $(3,030.2 \mathrm{kB})$ 